\title{
Leave or remain? The post-Brexit (im)mobility intentions of Bulgarians in the United Kingdom
}

European Urban and Regional Studies I-8

(C) The Author(s) 2020

(c) (1) (5)

Article reuse guidelines:

sagepub.com/journals-permissions DOI: $10.1177 / 0969776420977603$ journals.sagepub.com/home/eur

@SAGE

\author{
Eugenia Markova \\ University of Brighton, UK \\ Russell King \\ University of Sussex, UK; Malmö University, Sweden
}

\begin{abstract}
In the light of impending Brexit, what factors shape European Union migrants' plans to remain in or leave the UK? Based on an online survey of 360 Bulgarians, an under-researched migrant group in the UK, this study finds that the ones who plan to remain have lived longer in the UK, are skilled professionals and are well integrated into the labour market. Contrastingly, respondents who feel that they will be discriminated against in the labour market or in setting up a business are more likely to intend to leave post-Brexit.
\end{abstract}

\section{Keywords}

Brexit, Bulgarian migrants, discrimination, immobility, labour market integration, skills

\section{Introduction}

The 2016 referendum on whether the UK should remain in or leave the European Union (EU) was a deeply disturbing event for the 3.3 million EU migrants living in the UK at the time. Overnight, they were confronted with an ironically analogous decision: should they remain in the UK or should they leave? The American economist Joseph Berliner (1977) wrote that 'when a person chooses an occupation ... or a place of residence, he [sic] expects that choice to endure for some period of time. It takes a force of some magnitude to induce a change'. What is the magnitude of the 'Brexit' force that it could induce a change in the lives of EU nationals residing and working in the UK? How is this change dependent on migrants' skills and position in the UK labour market and their perceptions of their future situation? We deploy data from a recent online survey of Bulgarians living in the UK to answer these questions.

Following the referendum result, a flurry of predominantly qualitative studies, based on small- $N$ interview samples, recorded the reactions of EU migrants to the generally unanticipated 'Leave' outcome. ${ }^{1}$ Amongst other topics, these studies explored the dilemmas of decision-making and forward planning in the light of impending Brexit, and spoke of the uncertainty provoked by slow-moving UK-EU

\footnotetext{
Corresponding author:

Eugenia Markova, Brighton Business School, University of Brighton, Mithras House, Lewes Rd., BN2 4AT Brighton, UK. Email: E.Markova2@brighton.ac.uk
} 
negotiations and the repeated postponement of the formal date of leaving. Conceptually, these studies, based on the reactions of interviewee-participants, framed Brexit as a 'rupture' (Owen, 2018), an 'unsettling event' (Kilkey and Ryan, 2020) and an 'impasse' (Anderson et al., 2020) which had not only profound political ramifications but also disturbing impacts on the migrants, both psychologically and in terms of planning their future lives. As a result of the 'atmosphere' surrounding Brexit, some EU migrants in the UK suddenly felt 'victimised' and 'unwanted' (Mazzilli and King, 2018). Increased episodes of racist behaviour, including hate speech and other forms of discrimination, were reported and experienced (Guma and Jones, 2019; Rzepnikowska, 2019). Whilst, for some, the result was a mobilisation of what Lulle et al. (2018) called 'tactics of belonging' and the affirmation of their moral and economic rights to stay in the UK, for others processes of 'unbelonging' (Mas Giralt, 2020) were set in motion.

All of the above qualitative studies - in terms of their empirical data collection - were carried out in the protracted period of uncertainty between the date of the referendum, June 2016, and January 2019, when the then Prime Minister, Theresa May, launched a settlement scheme for EU nationals who wanted to remain long-term in the UK. At the time of writing (July 2020), more than 3.3 million EU citizens have acquired 'settled' or 'pre-settled' status (Home Office, 2020), a remarkable response which indicates the desire of the vast majority to remain in the UK, despite the changed political and social atmosphere, and outnumbering the countervailing tendency for a 'Brexodus' of EU migrants.

These aggregate data on EU citizens' plans to remain in the UK also speak to a wider conceptual debate: the extent to which intra-EU migration can be characterised as 'liquid migration' (Engbersen and Snel, 2013), a kind of open-ended, semi-spontaneous, back-and-forth mobility of EU citizens enjoying their freedom-of-movement rights. Other authors questioned the 'liquid' nature of such movements, arguing instead for a progressive 'grounding' (Bygnes and Erdal, 2017) and 'social anchoring' (GrzymalaKazlowska, 2018) of intra-European migrants. 'Grounded' or 'anchored' lives are shaped by the 'solidifying' achievements of educational and training qualifications, career advancement, property acquisition, cultural capital accumulation and changes in personal circumstances, such as the formation of romantic partnerships and the birth of children.

Our study claims three advantages over prior studies on EU migrants in 'Brexiting Britain'. First, as already stated, previous research remains bounded within a time frame of uncertainty and insecurity before the UK government's announcement of the settlement scheme for EU nationals at the start of 2019. Second, previous studies have not quantitatively investigated the relationship between future plans (leave or remain in the UK) and migrants' labour market integration, including skill characteristics. Third, this study is novel because of the paucity of research on Bulgarians in the UK. ${ }^{2}$

The paper is organised as follows. The next two sections discuss the background to Bulgarian migration to the UK and the conceptual framework for analysing the post-Brexit plans of the migrants, focusing on their diverse skill profiles and labour market integration, as well as their perceptions and experiences of discrimination. Then we describe the survey and respondent characteristics. The succeeding section presents and discusses the results of the empirical analysis, followed by a brief conclusion.

\section{Background to Bulgarian migration to the UK}

Bulgaria joined the EU in 2007, along with Romania, as part of the 'second phase' of eastern enlargement, following the much greater enlargement of 2004. However, there was an important earlier history of Bulgarian migration to the UK, including political dissidents during the Cold War (Markova, 2010). A transition period (2007-2013) was only partially effective in holding off the inflow to the UK, which accelerated after 2013 and, indeed, after the referendum. Office for National Statistics figures show that the number of Bulgarians in the UK grew sharply from just over 5,000 at the 2001 Census to 49,000 in $2011,76,000$ in 2016 and 128,000 in 2019. Table 1 shows that the post-referendum increase was especially marked in the London region and Eastern England, where the numbers more than doubled. 
Table I. Geographical distribution of Bulgarian nationals in the UK, pre- and post-referendum.

\begin{tabular}{|c|c|c|}
\hline & $\begin{array}{l}\text { Jul 2015-Jun } \\
2016\end{array}$ & $\begin{array}{l}\text { Jan-Dec } \\
2019\end{array}$ \\
\hline UK & 76,000 & 128,000 \\
\hline England & 69,000 & 117,000 \\
\hline North East & 1000 & c \\
\hline North West & 5000 & 6000 \\
\hline Yorkshire and the Humber & 1000 & 4000 \\
\hline East Midlands & 2000 & 4000 \\
\hline West Midlands & 8000 & 9000 \\
\hline East & 6000 & 11,000 \\
\hline London & 32,000 & 65,000 \\
\hline inner London & 17,000 & 18,000 \\
\hline outer London & 15,000 & 46,000 \\
\hline South East & 11,000 & 13,000 \\
\hline South West & 5000 & 6000 \\
\hline Wales & 2000 & 3000 \\
\hline Scotland & 4000 & 6000 \\
\hline Northern Ireland & c & 2000 \\
\hline
\end{tabular}

Source: Office for National Statistics data, compiled by the authors.

c: data not available due to disclosure control; therefore, totals may not tally exactly.

Table 2 compares Bulgarians' occupational profiles with the UK national average. Bulgarians are half as likely to be in senior positions - as managers, directors and, in professional and administrative occupations. On the other hand, they are approximately twice as likely to be employed in skilled trades, including machine operatives and allied jobs, and three times more likely to be in elementary occupations. The typical working patterns of Bulgarians (and Romanians, who have very a similar profile) are characterised by long working weeks (61\% work more than 40 hours, compared with the UK national average of $32 \%$ ) and their median hourly pay, $£ 8.33$, is the lowest of all workers (ONS, 2017).

\section{Conceptual orientation}

Alongside the notions of disruption, Brexit anxieties, liquid migration and grounding outlined in the introduction, our thinking is also informed by economic and labour market principles. A core
Table 2. Distribution of Bulgarian citizens and total UK population, of working age, in employment, by occupation, 2014-2106, in \%.

\begin{tabular}{|c|c|c|}
\hline & Bulgarian & $\begin{array}{l}\text { UK national } \\
\text { average }\end{array}$ \\
\hline $\begin{array}{l}\text { Managers, directors, } \\
\text { senior officials }\end{array}$ & 4.0 & 10.2 \\
\hline Professional occupations & 10.7 & 20.0 \\
\hline $\begin{array}{l}\text { Associate professional, } \\
\text { technical occupations }\end{array}$ & 7.3 & 14.3 \\
\hline $\begin{array}{l}\text { Administrative, secretarial } \\
\text { occupations }\end{array}$ & 4.7 & 10.6 \\
\hline Skilled trades occupations & 19.9 & 10.7 \\
\hline $\begin{array}{l}\text { Caring, leisure, other } \\
\text { service occupations }\end{array}$ & 8.0 & 9.3 \\
\hline $\begin{array}{l}\text { Sales, customer service } \\
\text { occupations }\end{array}$ & 3.6 & 7.8 \\
\hline $\begin{array}{l}\text { Process, plant, machine } \\
\text { operatives }\end{array}$ & 12 & 6.4 \\
\hline Elementary occupations & 29.8 & 10.7 \\
\hline TOTAL & 100.0 & 100.0 \\
\hline
\end{tabular}

Source: Authors' calculations based on Office for National Statistics (2017) data.

argument of this paper is that secure legal status, albeit acquired in a country which has voted to leave the EU partly due to anti-immigrant sentiments among its population, facilitates successful labour market integration and feelings of relative personal advantage which, in turn, incentivises remaining in the host country. Following this logic, the more skilled and successful migrants are less likely to return to their home countries - where their human capital is under-rewarded - and more likely to remain in a country with higher returns to their skills (Ghosh, 1996). Hence, immobility, defined as the self-reported intention to remain long-term in the host country, is our key dependent variable.

The process of migrants' decision-making is further examined by Schewel's (2020) aspiration-capability model, where immobility is influenced by a combination of 'retain' and 'repel' factors. Neoclassical economic theory suggests that migrants behave as rational actors basing their decisions on well-informed costbenefit calculations. Other migrants, however, may privilege 'capabilities' and 'choices' where higher income is not the top priority, although its significance 
is not overlooked. Schewel (2020: 339) discusses the importance of economic and social embeddedness in migrants' propensity to stay put. The longer people stay in one place, the less likely they are to pursue a change. Social anchoring factors, such as family, children and established community relations, appear to be particularly important in the decision to remain (Grzymala-Kazlowska, 2018).

Repel factors for Bulgarians in the UK encompass, in addition to the upcoming reality of Brexit, an array of unfavourable policy developments associated with the Conservative government's longstanding 'hostile environment' toward immigrants (Goodfellow, 2019), negative media portrayals of migrants from 'underdeveloped' Eastern European countries, and actual or perceived discrimination or racism based on ascribed behavioural and cultural characteristics (Fox et al., 2012).

\section{Data collection and analysis}

The analysis utilises data from an online survey of Bulgarians living and working in the UK, conducted during March-April 2019. A total of 360 respondents answered questions on their migration history, demographic characteristics, living and working conditions, and - of particular relevance to this paper - reactions to the 2016 referendum. Three open-ended questions prompted respondents to elaborate on their reasons for migration, their decision to settle in the UK and their concerns over Brexit. The link to the questionnaire (which was in Bulgarian) was publicised through regional Facebook groups of Bulgarian community associations, language schools, ethnic shops and dance groups, as well as personal contacts and cold calls in public spaces.

An important issue related to a survey of this type concerns the generation of a random sample of respondents. The selection of individuals is, to some degree, associated with their social media visibility. If the unobservable characteristics that encourage the use of social media and engagement in ethnic affairs are highly correlated with the decision to remain in the UK long-term, there is a potential bias in the 'leave or remain' decision function. Moreover, those who have already departed the UK are not captured by the survey. Response biases in terms of gender and education are evident in the survey, with women and those with tertiary-level qualifications over-represented ( $73 \%$ and $60 \%$, respectively). These limitations are counterbalanced, to a degree, by the multiplicity of survey entry-points and the detail of information obtained. The final sample - potentially indicative of the Bulgarian population in the UK includes respondents with a diverse range of social, demographic and economic characteristics in terms of place of residence in the UK, citizenship and residence status, age, education, English-language skills, duration of stay and labour market experience. Nonetheless, given the sampling process, care must be taken not to generalise the findings of this study to all Bulgarians residing in the UK.

From the extensive array of information collected by the online survey, we select specific characteristics of the sample which are germane to the question at hand (Table 3 ). The median age of the sample is 38 and the average duration of residency in the UK is 5.17 years. Over two-thirds have a family member in the UK and over a quarter have children in the country. More than half of the sample are residing in the London area and the South East. Some $44 \%$ are in high- and upper-middle-skilled jobs. These variables are indicative of longer-term, stable integration and therefore a desire to remain in the UK. On the negative side, close to one third of respondents envisioned being discriminated against in the labour market, and a third perceived that they would earn more if they were not Bulgarian. Meanwhile, over half have legalised their status in the UK, either through dual Bulgarian-British citizenship or via the scheme to acquire settled or pre-settled status - an indication of a commitment to remain in the country.

Table 4 indicates that earlier arrivals to the UK are more likely to remain post-Brexit. Those who have been in the UK longer are more likely to be older, to be married or in a stable romantic partnership (including with a non-Bulgarian), to have children and to own a property - all factors that anchor them to the place where they are currently living and make it more difficult to 'up sticks' and leave. They may be experiencing the social embeddedness or 'grounding' that leads them gradually to regard the UK as their long-term 'home' (Bygnes and Erdal, 2017; Schewel, 2020). 
Table 3. Main characteristics of survey respondents.

\begin{tabular}{|c|c|}
\hline \multicolumn{2}{|l|}{ General } \\
\hline \multicolumn{2}{|l|}{$\begin{array}{l}\text { Intentions to remain for certain in the } \\
\text { UK post-Brexit, } n=295\end{array}$} \\
\hline Yes & $47 \%$ \\
\hline Median age (in years), $n=357$ & 38 \\
\hline $\begin{array}{l}\text { Median length of residency in the UK } \\
\text { (in years: min; max), } n=356\end{array}$ & $\begin{array}{l}5.17 \\
\operatorname{Min}=0.08 \\
\max =37.33\end{array}$ \\
\hline $\begin{array}{l}\text { Legal status (declared holding British } \\
\text { citizenship, settled status or current } \\
\text { applications for these) }\end{array}$ & $57 \%$ \\
\hline \multicolumn{2}{|l|}{$\begin{array}{l}\text { Region of residency, } \\
n=338\end{array}$} \\
\hline London & $33 \%$ \\
\hline South East & $25 \%$ \\
\hline South West & $9 \%$ \\
\hline East Midlands & $7 \%$ \\
\hline East of England & $5 \%$ \\
\hline West Midlands & $5 \%$ \\
\hline North East & $5 \%$ \\
\hline North West & $5 \%$ \\
\hline Scotland & $3 \%$ \\
\hline Wales & $2 \%$ \\
\hline Yorkshire and the Humber & $2 \%$ \\
\hline \multicolumn{2}{|l|}{ Labour market integration and skills } \\
\hline $\begin{array}{l}\text { Very good English language written } \\
\text { skills, } n=339\end{array}$ & $56 \%$ \\
\hline \multicolumn{2}{|l|}{ Current/last job, $n=262$} \\
\hline High-skilled & $24 \%$ \\
\hline Upper-middle-skilled & $20 \%$ \\
\hline Lower-middle-skilled & $27 \%$ \\
\hline Low-skilled & $29 \%$ \\
\hline \multicolumn{2}{|l|}{$\begin{array}{l}\text { Perceived discrimination post- Brexit, } \\
n=312\end{array}$} \\
\hline Yes & $30 \%$ \\
\hline \multicolumn{2}{|l|}{ Expected higher income if not } \\
\hline Yes & $33 \%$ \\
\hline \multicolumn{2}{|l|}{ Family characteristics } \\
\hline \multicolumn{2}{|l|}{ Family members in the UK, $n=360$} \\
\hline Yes & $74 \%$ \\
\hline \multicolumn{2}{|l|}{ Children in the UK, $n=360$} \\
\hline Yes & $28 \%$ \\
\hline Mean number of children in the UK & 0.38 \\
\hline
\end{tabular}

Source: Questionnaire Survey, March-April 2019.

Amongst the written answers to the open-ended question about reasons to stay in the UK, frequent
Table 4. Distribution of respondents by year of arrival (time in the UK) and intentions to remain in the UK post-Brexit (\% in parenthesis).

\begin{tabular}{lcc}
\hline Year of arrival (grouped) & Leave & Remain \\
\hline $1989-1999$ & 2 & 10 \\
& $(1.2)$ & $(7.2)$ \\
$2000-2006$ & 12 & 19 \\
& $(7.7)$ & $(13.8)$ \\
$2007-2013$ & 59 & 49 \\
& $(38.1)$ & $(35.5)$ \\
$2014-2016$ & 52 & 42 \\
& $(33.5)$ & $(30.4)$ \\
$2017-$ & 30 & 18 \\
& $(19.4)$ & $(13.0)$ \\
Total & 155 & 138 \\
& $(100.0)$ & $(100.0)$ \\
\hline
\end{tabular}

Source: Questionnaire Survey, March-April, 2019.

Note: $\left(\right.$ Chi-square $\left.=12.025^{* *}, d f=4, p=0.034\right)$. When the duration of residence is measured in years, Pearson's $r=$ $0.157^{* * *}, p=0.007,2$-tailed; $* *$ and $* * *$ denote statistical significance at the 0.05 and 0.01 levels of significance respectively.

references were made to this 'settling down' process, including marriage, children and the possibility of a 'normal life' - unattainable, in their view, in Bulgaria (cf. Manolova, 2019). The following is a typical quote from a nurse:

As well as my job, I choose to stay here because of the organised way of life. Here there are rules and laws that are followed, unlike in Bulgaria where there is only corruption, nepotism, impunity. . .

Other respondents referred repeatedly to notions such as 'better education for my children', 'security of employment', 'my partner is British', and 'a healthier living environment', in order to justify their decision to remain. ${ }^{3}$

Higher-skilled professionals and the upper-middle-skilled are significantly more likely to remain (Table 5). These respondents perceive and experience work and income in the UK as decidedly more advantageous than returning to Bulgaria, where their qualifications would be less-well rewarded, if at all (Ghosh, 1996). Beyond the income aspect, respondents appreciated the favourable promotion possibilities as well as the better working conditions and employment 
Table 5. Distribution of respondents by profession and intentions to remain in the UK post-Brexit (\% in parentheses).

\begin{tabular}{lcc}
\hline & Leave & Remain \\
\hline High-skilled & 26 & 35 \\
& $(19.8)$ & $(30.4)$ \\
Upper- & 21 & 24 \\
middle-skilled & $(16.0)$ & $(20.9)$ \\
Lower- & 44 & 26 \\
middle-skilled & $(33.6)$ & $(22.6)$ \\
Low-skilled & 40 & 30 \\
& $(30.5)$ & $(26.1)$ \\
Total & 131 & 115 \\
& $(100.0)$ & $(100.0)$ \\
\hline
\end{tabular}

Source: Questionnaire Survey, March-April 2019.

Note: (Chi-squared $=6.572 *, d f=3, p=.087) ; *$ denotes

statistical significance at the 0.10 level.

Table 6. Perceptions of labour market discrimination and mobility intentions ( $\%$ in parentheses).

\begin{tabular}{lcc}
\hline & Leave & Remain \\
\hline I won't be & 99 & 104 \\
discriminated against & $(65.1)$ & $(77.0)$ \\
I will be & 53 & 31 \\
discriminated against & $(34.9)$ & $(23.0)$ \\
Total & $\mathbf{1 5 2}$ & $\mathbf{1 3 5}$ \\
& $(\mathbf{1 0 0 . 0 )}$ & $\mathbf{( 1 0 0 . 0 )}$ \\
\hline
\end{tabular}

Source: Questionnaire Survey, March-April, 2019.

Note: (Chi-squared $=4.895^{* *}, d f=I, p=0.027$ );

Phi $=-0.13 \mid * * ; *$ denotes statistical significance at the 0.05 level.

protection available in Britain. The following are two typical quotes, the first from an anaesthetist:

I feel I am developing and growing in my profession. In three years, I have become a consultant. I am living a normal life.

The second is from a skilled tradesperson:

Better income here and they [employers] recognise me as a person. If I am sick and call my manager, he tells me 'No problem; take time to rest and recover'; while in Bulgaria nobody cares if you are healthy - if you cannot go to work they fire you.
Table 6 cross-tabulates perceptions of being discriminated against when looking for work or setting up a business, and mobility. A significant negative association is found between the two variables (phi $=-0.131, p<5 \%$ ). A person who experiences this perceived relative deprivation (cf. Stark, 1991) is more likely to intend to leave the UK post-Brexit. Conversely, as confirmed by the previous two quotes from respondents, those who experience career advancement and appreciation at work are more likely to remain in the UK.

Regionally, respondents in London, the South East and the Midlands are more prone to want to stay, whereas in Scotland, Wales and Eastern England they are more inclined to leave. Differing skill levels are partly behind this regional contrast. For instance, over two-thirds of those in London wanting to remain are in high- and upper-middleskilled jobs, including health professionals, engineers and university staff. Three-quarters of those intending to leave in the East region, and two-thirds in Wales, are low- and lower-middle-skilled workers. Of course, these associations are not absolute: a live-in care worker in the South East explained her decision to leave in terms of the inaccessible cost of housing, whereas a carpenter, also in the South East, voiced a different perspective: 'I think those who want to work will stay; those who want to live on social support, they will leave.'

\section{Conclusion}

Despite media reports of a 'Brexodus' of EU migrants returning to their home countries, evidence from this survey of Bulgarians shows that many want to stay in the UK. They are actively anchoring themselves through civic integration, and successful employment and careers, as well as grounding their personal and emotional lives here. Moreover, their numbers continue to grow - by more than two-thirds since the referendum, according to official statistics. Whilst recognising that the online survey does not capture a fully representative sample, it does seem that the proclivity of the more successful migrants to want to stay put will benefit both themselves and the UK regional economies. What this means for the Bulgarian economy and society is another, more 
complex, story and beyond the scope of this brief paper.

\section{Acknowledgements}

The author(s) would like to thank the three anonymous reviewers for their constructive comments; the Bulgarian respondents in the UK who completed the online survey, making this research possible; the University of Brighton's Ethics Committee for granting a positive decision on the commencement of the study; and, Ekaterina Tosheva, for her support with it.

\section{Declaration of conflicting interests}

The author(s) declared no potential conflicts of interest with respect to the research, authorship, and/or publication of this article.

\section{Funding}

The author(s) received no financial support for the research, authorship, and/or publication of this article.

\section{ORCID iD}

Eugenia Markova (iD https://orcid.org/0000-0002-9599 $-1585$

\section{Notes}

1. Space limitations prevent a full listing of publications on Brexit and migration. For useful collections see the special issues of Population, Space and Place edited by Botterill et al. (2019) and Central and Eastern European Migration Review, edited by Kilkey et al. (2020).

2. On Bulgarian migration to the UK, see Genova and Zontini (2020); Manolova (2019).

3. This collective articulation of 'social anchoring' (Grzymala-Kazlowska, 2018) and 'grounded lives' (Bygnes and Erdal, 2017) is at odds with other research on EU migrants in London which suggests a return to the home country to bring up children in a safer, cleaner and lower-cost environment than the expensive, crowded, polluted British capital (e.g. King et al., 2018).

\section{References}

Anderson B, Wilson HF, Foreman PJ, Heslop J, Ormerod E and Maestri G (2020) Brexit: Modes of uncertainty and futures in an impasse. Transactions of the Institute of British Geographers 45(2): 256-269.
Berliner J (1977) Internal migration: A comparative disciplinary view. In: Brown AA and Newberger E (eds) Internal Migration: A Comparative Perspective. New York: Academic Press, 443-461.

Botterill K, McCollum D and Tyrrell N (eds) (2019) Negotiating Brexit: Migrant spacialities and identities in a changing Europe. Population, Space and Place 25(1): 1-4.

Bygnes S and Erdal MB (2017) Liquid migration, grounded lives: Considerations about future mobility and settlement among Polish and Spanish migrants in Norway. Journal of Ethnic and Migration Studies 43(1): 102-118.

Engbersen G and Snel E (2013) Liquid migration: Dynamic and fluid patterns of post-accession migration flows. In: Glorius B, Grabowska-Lusinska I and Kuvik A (eds) Mobility in Transition: Migration Patterns after EU Enlargement. Amsterdam: Amsterdam University Press, 21-40.

Fox JE, Moroşanu L and Szilassy E (2012) The racialization of new European migration to the UK. Sociology 46(4): 680-695.

Genova E and Zontini E (2020) Liminal lives: navigating in-betweenness in the case of Bulgarian and Italian migrants in Brexiting Britain. Central and Eastern European Migration Review 9(1): 47-64.

Ghosh B (1996) Economic migration and the sending countries. In: van den Broeck J (ed) The Economics of Labour Migration. Cheltenham: Edward Elgar, 77-114.

Goodfellow M (2019) Hostile Environment: How Immigrants Became Scapegoats. London: Verso.

Grzymala-Kazlowska A (2018) From connecting to social anchoring: Adaptation and 'settlement' of Polish migrants in the UK. Journal of Ethnic and Migration Studies 44(2): 252-269.

Guma T and Jones RD (2019) 'Where are we going to go now?' European Union migrants' experiences of hostility, anxiety and (non-)belonging during Brexit. Population, Space and Place 25(1): 1-10.

Home Office (2020) EU Settlement Scheme Statistics, May 2020; Experimental Statistics, 18 June. Available at: https://www.gov.uk/government/statistics/eu-settlement-scheme-statistics-may-2020 (accessed 9 July 2020).

Kilkey M and Ryan L (2020) Unsettling events: Understanding migrants' responses to geopolitical transformative episodes through a life-course lens. International Migration Review. DOI: 10.1177/0197918320905507. 
Kilkey M, Piekut A and Ryan L (eds) (2020) Brexit and beyond: Transforming mobility and immobility. Central and Eastern European Migration Review 9(1): 5-12.

King R, Lulle A, Parutis V and Saar M (2018) From peripheral region to escalator region in Europe: Young Baltic graduates in London. European Urban and Regional Studies 25(3): 284-299.

Lulle A, Moroşanu L and King R (2018) And then came Brexit: Experiences and future plans of young EU migrants in the London region. Population, Space and Place 24(1): 1-11.

Manolova P (2019) 'Going West is my last chance to get a normal life': Bulgarian would-be migrants' imaginings of life in the UK. Central and Eastern European Migration Review 8(2): 61-83.

Markova E (2010) Effects of immigration on sending countries: Lessons from Bulgaria. GreeSE Paper 35, London, London School of Economics, Hellenic Observatory on Greece and Southeast Europe.

Mas Giralt R (2020) The emotional geographies of migration and Brexit: Tales of unbelonging. Central and Eastern European Migration Review 9(1): 29-45.
Mazzilli C and King R (2018) 'What have I done to deserve this?' Young Italian migrants in Britain narrate their reaction to Brexit and plans for the future. Rivista Geografica Italiana 125(3): 507-522.

ONS (2017) Living Abroad: Dynamics of Migration between the UK and the EU2, 11 October. Available at: https://cy.ons.gov.uk/peoplepopulationandcommunity/populationandmigration/internationalmigration/ articles/livingabroad/dynamicsofmigrationbetweenbritainandtheeu2 (accessed 10 October 2020).

Owen C (2018) Brexit as rupture? Voices, opinions and reflections of EU migrants from the liminal space of Brexit Britain. Working Paper 94, Brighton, Sussex Centre for Migration Research, University of Sussex. Rzepnikowska A (2019) Racism and xenophobia experienced by Polish migrants in the UK before and after Brexit vote. Journal of Ethnic and Migration Studies 45(1): 61-77.

Schewel K (2020) Understanding immobility: Moving beyond the mobility bias in migration studies. International Migration Review 54(2): 328-355.

Stark O (1991) The Migration of Labor. Cambridge, MA: Basil Blackwell. 